\title{
The Jealous Institution: Male Nubility, Conjugality, Sexuality, and Discipline on the Social Margins of Imperial Brazil
}

\author{
PETER M. BEATTIE \\ History, Michigan State University
}

In 1997, an "attempted rebellion" erupted in the Professor Barreto Campelo Penitentiary on Itamaracá Island, Pernambuco. A journalist reported that the suspension of conjugal visits sparked a brawl in which three inmates were stabbed before guards restored order. The warden clarified that conjugal visits had been suspended after fights broke out between rival cellblocks when someone pilfered objects visitors had brought to prisoners. A woman who desired anonymity informed, "The convicts notified us in the afternoon by way of notes that they would fight again that night. I think that the lack of contact with their female companions leaves all of the men agitated." The warden brokered a truce with the inmates' leaders in part by promising that conjugal visits would resume the next week. The reporter concluded, almost as an afterthought, that inmates renewed protests about the overcrowding of eleven hundred inmates into a jail designed for four hundred. ${ }^{1}$

Acknowledgments: I thank B. J. Barickman, Dain Borges, Marcus Joaquim Maciel de Carvalho, Celso Castilho, Lisa M. Fine, Donna Guy, Elizabeth Anne Kuznesof, the Newberry Library Latin American History Seminar participants, Micol Seigel, Barbara Weinstein, Michigan State University's Last Friday Latin American history group (Edward Murphy, Benjamin T. Smith, David Wheat, and Erica M. Windler) and four anonymous $C S S H$ reviewers for their insightful comments on this manuscript. I claim all rights to any mistakes of fact or interpretation herein. I also thank Fulbright CIES and Michigan State University's Intramural Research Grant Program, the Department of History, and International Studies and Programs for the support that made this research possible.

${ }^{1}$ Jornal do Commercio, Recife, 26 June 1997, 1. I cite other rebellions over conjugal visits in Beattie, "“Cada homen traz dentro de si sua tragedia sexual': Visitas Conjugais, Gênero, e Lemos Britto's A Questão sexual nas prisões (1934)," in Clarissa Nunes Maia, Flávio de Sá Neto, Marcos Costa, and Marcos Luiz Bretas, eds., Prisão, prisioneiros e sociedade - sécs. XVIII-XXI, 2 vols. (Rio: Editoria Rocco, 2009), II, 215-47. 
The interpretations of these events reflect assumptions about male sexuality. Whether lack of access to female partners ignited this conflict, as opposed to overcrowding, the reporter and informant implied that it was the trigger because it left the inmates "agitated" (nervosos). As Nancy Scheper-Hughes shows, nervoso is an expansive, polysemic concept that embodies physical and mental conditions of weakness that poor Brazilians have long used to describe a medical, psychic, and social condition which creates a curative mystique that obscures the root cause of their poor health: malnutrition. The anonymous female informant stretched the term to describe sexual hunger as a bodily need that if unfulfilled could lead men to violence. ${ }^{2}$

Interpretations of this conflict echo those that long worried officials who grappled with discipline in institutions that segregate men to varying degrees from women. Does intimate contact with women improve discipline, ${ }^{3}$ and if so, how should it be regulated? By examining how nineteenth-century Brazilians grappled with these questions, I explore enduring notions of gender, sexuality, discipline, health, reform, and justice. Specifically, I argue that powerful social actors often viewed heterosexual conjugality and marriage as a means to rank, control, reward, and motivate a minority of subordinate men in coercive labor regimes. Many secular and religious authorities in Brazil came to articulate a strong belief in what I term "the jealous institution" of heterosexual conjugality and marriage for men in a hodgepodge of hierarchically ranked marginal status groups, for a variety of overlapping reasons. First, leaders of a vast and thinly populated nation undergoing a transition from slave to free labor concerned themselves with population growth. Second, they shared socially constructed interpretations of bio-sexual needs in relation to "natural" gender proclivities, morality, and pyschobiological health. Third, they viewed the legal institution of marriage as a marker of status and a bellwether of a just public and private order, an order that actors great and small contested vigorously. Fourth, they believed that the privilege of conjugality gave them leverage over recalcitrant male workers. Finally, this practice developed from the contingencies presented by the everyday maintenance of order in different settings. ${ }^{4}$

The segregation from society that modern prisons, poor houses, asylums, barracks, and penal colonies required ran counter to critiques of inhibiting a

${ }^{2}$ Nancy Scheper-Hughes, Death without Weeping: The Violence of Everyday Life in Brazil (Berkeley: University of California Press, 1992), 167-215. Similar language of bodily hunger, gender, and sex remains part of Brazilian parlance. See, e.g., Richard Parker, Bodies, Pleasures and Passions: Sexual Culture in Contemporary Brazil, 2d ed. (Nashville: Vanderbilt University Press, 2009), 46-47, 121.

3 Elizabeth Abbot, A History of Celibacy (Cambridge, Mass.: Da Capo Press, 2001).

${ }^{4}$ For similar theories in colonial America, see Mary Beth Norton, Foundational Mothers and Fathers: Gendered Power and the Forming of American Society (New York: Vintage Books, 1996); on Brazil, Jurandir Freire Costa, Ordem médica e norma familiar, 3d ed. (Rio: Graal, 1989). 
man's heterosexual release through continence or imposed abstinence. ${ }^{5}$ Brazilians disagreed over the access priests, slaves, physicians, soldiers, and convicts should have to nubile women, but most shared beliefs about the inexorable male sex drive, even as they bickered over how to manage it. In English, nubile designates marriageable women, but in Portuguese, núbil applies to both genders. These usages suggest distinct cultural views of gender and marriage, and to highlight this, I use the incongruous label "male nubility" to designate the status of men to whom authorities granted heterosexual conjugal privileges within total institutions. To explore male nubility, I cull insights from two works of sociology to elucidate tensions between individuals, families, and segregating institutions. I then trace criticisms of gender-segregating institutions and the imposition of male heterosexual abstinence. This context permits a more meaningful exploration of policies regulating convict conjugality on Fernando de Noronha, which became home to the largest concentration of Brazil's convicts. The Portuguese founded the island colony some 200 miles off Brazil's coast in 1737, but, unable to attract voluntary migrants, it sent penal exiles and soldiers from Brazil to inhabit it. Brazilians claimed the island after independence in 1822 and continued to people it with convicts and soldiers. In 1865, new regulations encouraged some bachelor convicts to marry, and formally permitted married convicts to petition for their wives and dependents to join them. This policy and its outcomes are the crux of this case study. ${ }^{6}$

I will compare this conjugal penal policy with other institutions that sought to discipline poor men whom the privileged assumed belonged to the less-tractable working class. For analytical purposes, I refer to convicts, slaves, and military enlisted men with a single term of my own device, "the intractable poor," which reflects powerful social actors' stereotypes of these social categories as unruly, wanton, and shiftless. By comparing convict workers to those in related coercive labor regimes, the approach highlights patterns less visible when they are examined separately. In my conclusion, I ponder how aspects of my approach might be profitably applied to other contexts.

INDIVIDUALS, FAMILIES, AND GENDER-SEGREGATING INSTITUTIONS

Like the narrative of the 1997 Itamaracá uprising, recent scholarship has stressed prisons' interconnectedness to their communities. To whit, David Garland appraises the Marxist, Durkheimian, Weberian, and Foucauldian traditions in

\footnotetext{
5 Authorities allowed single women convicts on Fernando de Noronha to marry if no religious impediments barred a couple's nuptials, but most authorities assumed women to be sexually passive and did not believe that they required sex to maintain their health, unlike men. Indeed, they thought that inappropriate sexual arousal could be hazardous to a woman's health. See, for example, Alexandre Augusto de Almeida Camillo, $O$ onanismo da mulher, sua influencia sobre o physico e a moral (Rio: Portella, 1886), 39.

6 Mario Carneiro do Rego Melo, Archipélago de Fernando de Noronha: Geographia physica e política (Recife: Imprensa Industrial, 1916).
} 
penology and accents the need to combine strengths of each to create "more of a three dimensional perspective than is usually perceived." I I share Garland's view, and invoke two scholars whose work has been less cited in recent scholarship: Erving Goffman and Lewis Coser. They offer points of departure for rethinking gender, family, and other institutions to explore how Brazilians mediated the individualized punishment of liberal penal reform.

Goffman insightfully conveys the tensions between families and total institutions (penitentiaries, mental asylums, barracks, etc.):

Total institutions are ... incompatible with another crucial element of our society, the family. Family life is sometimes contrasted with solitary living, but in fact the more pertinent contrast is with batch living, for those who eat and sleep at work, with a group of fellow workers, can hardly sustain a meaningful domestic existence.... Whether a particular total institution acts as a good or bad force in civil society, force it will have, and this will in part depend on the suppression of the whole circle of actual or potential households. Conversely, the formation of households provides a structural guarantee that total institutions will not be without resistance.

While I agree with Goffman's assessment of these tensions in a contemporary U.S. context, nineteenth-century Brazilian authorities integrated batch and household living arrangements in selected total institutions. ${ }^{8}$

Inspired by Goffman, Coser defined a related group of greedy institutions that attempt to monopolize the primary loyalties of individuals from competing societal associations without necessarily segregating them from society like total institutions do. He identifies a range of greedy institutions, including those that cultivated individuals whose authority could not be preserved without the institutional leadership's support. Thus, sovereigns sought trusted administrators from court Jews, eunuchs, foreign mercenaries, and others. Likewise, the Catholic Church, radical organizations, and millenarian groups limit their members' abilities to develop entangling relationships that might put their loyalty to the test. The Church, for example, requires clerical celibacy to bolster fidelity to the hierarchy and to protect institutional property from dissipation through inheritance. Coser even includes housewives and live-in servants as subject to the greedy institution of the nuclear family. Writing in the 1970s, he notes feminist critiques of gender expectations that pressured housewives to limit commitments and contacts outside of the family in deference to their roles as mothers and caretakers. Coser does not address, however, whether the family limits husbands and fathers. ${ }^{9}$

\footnotetext{
${ }^{7}$ Garland, Punishment and Modern Society: A Study in Social Theory (Chicago: University of Chicago Press, 1990), 278.

${ }^{8}$ Goffman, Asylums: Essays on the Social Situation of Mental Patients and other Inmates (Chicago: Aldine Pub. Co., 1961), 11-12.

${ }_{9}$ Lewis A. Coser, Greedy Institutions: Patterns of Undivided Commitment (New York: The Free Press, 1974); Joan Scott, "Gender: A Useful Category of Analysis," American Historical Review 95, 5 (Dec. 1986): 1053-75.
} 
Intriguingly, many nineteenth-century Brazilian authorities (almost all men) posited that male jealousy for a wife or consensual partner "naturally" bound him to a more productive and moral lifestyle. Somewhere between and overlapping with Coser's greedy and Goffman's total institutions, Brazilian officials experimented with hybrid penal practices that combined modern and traditional elements of batch and family living to cultivate what I term the jealous institution. The jealous institution is a male corollary to Coser's hypothesis that the nuclear family was a greedy institution for wives and mothers. It describes the less restrictive but still limiting "natural" influence that conjugality, marriage, and family had over men. Authorities tested the potential of heterosexual penal conjugality on Fernando de Noronha, but to understand this experiment, a brief archeology of criticisms of male segregation and imposed sexual abstinence is needed.

\section{MALE CELIBACY AND GENDER SEGREGATION}

For many nineteenth-century Brazilians, sexual abstinence debilitated a man's health, and prisons, penal colonies, barracks, boarding schools, monasteries, and senzalas (gender-segregated slave barracks) were common sites of "perversion." As an 1898 Brazilian medical thesis on same-sex eroticism observed: "Religious communities, ocean going vessels, the navy, the army, boarding schools, and seminaries were in truth perfect habitats for the type of forbidden love we study." 10 Authorities blamed masturbation and same-sex liaisons in these institutions on women's relative absence.

Critics of segregating men from women borrowed from enlightenment attacks on the Catholic Church. For many, a man needed to realize himself through regular, but not excessive, heterosexual intercourse to maintain health. Ideally, this health treatment would come through regular couplings with a man's wife. For some, prostitutes were inferior proxies because they let single men satisfy their urges and reduced the threat of seduction or rape for honest women of families. If deprived of "natural" copulation with women, a man's insatiable sex drive would find release in "unnatural" desires such as "sodomy," bestiality, and masturbation. ${ }^{11}$

Eighteenth-century reformers applied aspects of this logic to criticize Brazil's monasteries, nunneries, and missions that they felt impeded Portuguese America's economic and demographic growth. Specifically, they ended the segregation of Indians in Jesuit-administered mission villages, and predicted that Indian women would then marry Portuguese men who would be a

\footnotetext{
10 Domingos Firmino Pinheiro, $O$ androphilismo (Bahia: Imprensa Econômica, 1898), 108. I thank Dain Borges for sharing this source.

11 Dain Edward Borges, The Family in Bahia, Brazil, 1870-1945 (Stanford: Stanford University Press, 1992), 100-1; José Gabriel de Lemos Britto, A Questão sexual nas prisões (Rio: J. Ribeiro dos Santos e Cia., 1934); Miguel Antônio Heredia Sá, "Algumas reflexões sobre a cópula, onanismo, e prostituição" (Rio: Typographia Universal de Laemmert, 1845).
} 
"civilizing" influence on their wives. The reformers' economic and sexual critiques buttressed attacks on Jesuit authority that ultimately facilitated their expulsion from Brazil in 1763. ${ }^{12}$ When there were not enough Indian women, Portuguese officials sent females from settled areas to frontiers to form families to stabilize rough and tumble outposts and discourage men forced to migrate there from deserting. Colonial officials during the Seven Years War dragooned "disreputable" women from São Paulo to send to Iguatemi, a frontier military settlement near the current Paraguayan border. This paralleled the crown's practice of granting dowries to orphaned Portuguese girls who they sent to colonial frontiers to wed. While many of these examples apply to Portugal's colonial frontiers, where this logic held particular appeal, similar practices applied in core plantation and urban areas. ${ }^{13}$

Brazilians shared Portuguese assumptions. A 1797 missive from the Recifeborn cleric Bernardo Luis Ferreira Portugal censured gender segregation policies on Fernando de Noronha:

On that island, the authorities do not allow women ... the lack of this sex gives birth to horrible crimes [such as] sodomy and bestiality ... the corruption is so deeply rooted that with pomp and publicity marriages between persons of the same-sex are celebrated, and these unfortunate ones call one another husband and wife: jealousies over attractive young men (ganimedes) cause frequent disorders, this vice attacks all from the commander to the last penal exile, and once habituated to it when they leave the island, they continue to practice it and introduce it [on the mainland]; ... These wrongs can only be corrected by altering ... the island's governance. All of the expenses that your majesty makes to sustain the troops and penal exiles ... all the evils of idleness that exist on that island can be resolved once you begin to populate it with married men.

Ferreira Portugal links order, productivity, and morality to the jealous institutional plow of heterosexual conjugality. This priest, who later became a leader of the failed 1817 Pernambucan Republican Revolution, argued that if the crown allowed married soldiers and convicts to live with their wives, and found suitable mates from "poor and honest people" for bachelors, they would become productive farmers who would export their goods and contribute to, rather than consume, crown revenues. Married men would be natural defenders of the isle, and women would extinguish same-sex eroticism. It is unclear if the crown mulled over Ferreira Portugal's ideas, but Brazilian officials later acted on them, indicating the jealous institution's ascendance in penal colonization. ${ }^{14}$

12 Leila Mezan Algranti, Honradas e devotas: mulheres da colônia (Rio: Editora José Olympio, 1993), 62-81; Kenneth Maxwell, Conflicts and Conspiracies: Brazil and Portugal, 1750-1808 (Cambridge: Cambridge University Press, 1973), 15-16.

${ }^{13}$ Henrique Peregalli, Recrutamento Militar no Brasil Colonial (Campinas: Edition da UNICAMP, 1986), 138-47; Timothy J. Coates compares empires' uses of penal exiles and orphans, in Convicts and Orphans: Forced and State-Sponsored Colonizers in the Portuguese Empire, 1550-1755 (Stanford: Stanford University Press, 2001), xv-xx, 141-62.

${ }_{14}$ Bernardo Luis Ferreira Portugal ao Dom Francisco de Souza Coutinho, Pará, 26 Dez., 1797, Biblioteca Nacional, Seção de Manuscritos, código 07-04-041; Brigadeiro Henrique de Beaurepaire Rohan, "A ilha de Fernado de Noronha," annexo in Relatorio apresentado á assemblea geral 
Brazilian reformers continued to criticize male celibacy after independence. The most famous was the liberal regent Padre Diogo Antônio Feijó, who favored abolishing clerical celibacy for Brazilian priests. Feijó held that obligatory celibacy went against "natural" rights and laws, and that the "propensity toward marriage was innate in the species." He added, "This is why it is so rare to find a celibate priest who is not perverse." One might mistakenly infer that this logic implicated Feijó himself, but it was well known that he had a mistress with whom he fathered five children. Traditionalists disagreed with Feijó and argued that sexual abstinence had no negative consequences for men, but the belief that it did continued to shape perceptions and practices. This view contrasted with many North Atlantic Victorians, who believed sexual continence was a sign of virility. ${ }^{15}$

Brazilian abolitionists and slavocrats employed a similar sexualized logic to attack the batch living common in senzalas. Masters stereotyped slaves as "vice-ridden" because they were not "of family," and though the logic was circular, this justified their enslavement and gender segregation, not to mention harsh punishment. The abolitionist Joaquim Nabuco often used this caricature: "He [the slave] does not possess his honor, because of his infamous birth and because his women are the inheritance of his master's lust.... Outside of the family, which he [a young slave] does not have, there are ... all the vices of servility - fear, cowardice, indignity, adulation, lies, and cynicism-which deposit themselves in fertile soil that is destined to burst forth in his youth." Nabuco depicted senzalas as dens of promiscuity:

An adolescent female slave of fifteen to sixteen years of age, sometimes younger ... is delivered already violated to the slave barracks. A female slave was born virtually without honor. Within reach of the first violence, without protection, without a tribunal, without a family, without law to which she can appeal, what can she do against such perfidy? There is no example for her except corruption, and thus a young woman of fifteen soon becomes a public woman in the senzala. Some masters present themselves

\footnotetext{
legislativa pelo ministro e secretario de negocios de guerra Visconde de Camamu (Rio: Typ. [Typographia] Laemmert, 1865), 29 [hereafter Relatorio ... guerra (minister's name)]; Raimundo José de Souza Lobo, Fernando de Noronha [hereafter, FN indicates correspondence from Fernando de Noronha], 1 July 1852, Arquivo Público de Pernambuco Jordão Emerenciano [hereafter, APPJE], FN-4e, f. 106; Gláucia Tomaz de Aquino Pessoa, Cadernos de pesquisa: Fernando de Noronha, uma ilha-presídio nos trópicos (Rio: Arquivo Nacional, 1994), 17.

${ }_{15}$ Diogo Antônio Feijó, Diogo Antônio Feijó, Jorge Caldeira, ed. (São Paulo: Editora 34, 1999), 279-357; Kenneth P. Serbin, Needs of the Heart: A Social and Cultural History of Brazil's Clergy and Seminaries (Notre Dame: University of Notre Dame Press, 2006), ch. 2; João José Reis observes that Padre Perereca (Luís Gonçalves dos Santos) penned a pamphlet criticizing Feijó's arguments against clerical celibacy in Death Is a Festival: Funeral Rights and Rebellion in Nineteenth-Century Brazil, H. Sabrina Gledhill, trans. (Chapel Hill: University of North Carolina Press, 2003), 239; Borges, The Family, 160, n. 27, 28; Gail Bederman, Manliness and Civilization: A Cultural History of Gender and Race in the United States, 1880-1917 (Chicago: University of Chicago Press, 1995); Ann Laura Stoler, Carnal Knowledge and Imperial Power: Race and the Intimate in Colonial Rule (Berkeley: University of California Press, 2002), 145-61.
} 
as arrangers of summary marriages: this is a sacrilege and impudence. Thrown from one to the other in the everyday bacchanalia, plaything of the most brutal instincts, she lives between giving birth and tortures.

New research shows that slaves formally wed at higher rates than previously thought, but the idea that they were "without family" remained ensconced in free Brazilians' imaginations. ${ }^{16}$

Abolitionists and slavocratic critiques proceeded from the assumption that bondage corrupted a slave's moral character because it allegedly denied him or her a nuclear family life, but they disputed whether that degradation extended to the families and the state that slave owners headed. The critiques of Fernando de Noronha, senzalas, barracks, and clerical celibacy reveal shared assumptions about male sexual needs that gained currency in the nineteenth century.

\section{"WITHOUT WOMEN IT IS IMPOSSIBLE TO GOVERN FERNANDO DE NORONHA"}

For many Latin Americans, penal reforms were touchstones of national progress toward "civilization." 17 Penal science offered an answer to seigniorial authority's decline as Brazil's slave population began to diminish after the transatlantic slave trade ended in 1850, but belief in rehabilitation confronted Cesare Lombroso's idea of "the born criminal" in the $1870 \mathrm{~s} .{ }^{18}$ Despite these theoretical countercurrents, most imperial penal officials espoused the reformative power of hard work, family living, and "normal" sexuality without reference to a convict's race, class, or condition (slave or free). The concept of the nuclear family as a foundation for societal order and labor discipline was not a new ideal of North Atlantic capitalism, as some have posited, but capitalism did influence how the family was conceptualized in relation to new institutions. ${ }^{19}$

Policies on Fernando de Noronha illuminate how officials used batch and household living to distinguish among convicts within Brazil's broader penal justice and labor systems. Brazil's 1824 Constitution and 1830 Penal Code called on provinces to build penitentiaries where the new sentence of prison at labor would be served. Only four provinces and the Capital District did so

16 Nabuco, A escravidão (Rio: Nova Fronteira, 1999 [1869]), 8-9, 30-32.

17 Carlos Aguirre and Ricardo Salvatore, "The Birth of the Penitentiary in Latin America: Toward an Interpretative Social History of Prisons," in Carlos Aguirre and Ricardo Salvatore, eds., The Birth of the Penitentiary in Latin America (Austin: University of Texas Press, 1996), $1-43$.

18 Though Cesare Lombroso had published earlier, he is probably best known for his Criminal Man, Mary Gibson and Nicole Hahn Rafter, trans. (Durham: Duke University Press, 2006 [1876]).

${ }^{19}$ Thomas Klubock argues that North American corporations introduced bourgeois family ideals to Chilean miners by privileging married workers in the El Teniente mines, in Contested Communities: Class, Gender, and Politics in Chile's El Teniente Copper Mine, 1904-1951 (Durham: Duke University Press, 2001). On new efforts to reform the poor in imperial Brazil, see, e.g., Walter Fraga Filho, Mendigos, moleques, e vadios na Bahia do Século XIX (São Paulo: Editoria Hucitec, 1996); Erica M. Windler, "City of Children: Boys, Girls, Family and State in Imperial Rio de Janeiro," (PhD diss., University of Miami, Coral Gables, 2003). 
during the empire, and none of them consistently provided work for inmates or followed other basic tenets of modern penal reform such as segregation by gender, age, and severity of crime. One option for officials was to petition to send inmates to the institution that did require labor: Fernando de Noronha. The island penal colony's convict population came to exceed the intended capacity of all of Brazil's new penitentiaries combined. ${ }^{20}$

Brazil's penal system cannot be separated from the slave regime that surrounded and penetrated it. Mainland jails and Fernando de Noronha held slave convicts alongside free prisoners of all colors. In 1850, when the state closed the transatlantic slave trade, some 30 percent of Brazil's population was bonded. By 1872 there were only 1.5 million slaves (16 percent of the population), and their numbers continued to dwindle until abolition in 1888 . Brazil's 1872 census identified 38 percent of 9,930,478 inhabitants as "white," some 16 percent as black, 4 percent as indigenous, and 42 percent as of mixed African and European heritage. ${ }^{21}$ Given Brazil's legacy of slavery, it is not surprising that white convicts were underrepresented in the colony whereas black, brown, and indigenous men were over-represented.

Since Recife's port supplied the colony, Pernambuco's governors shared in its administration with the War Ministry in distant Rio de Janeiro. This continued until 1877, when Parliament transferred its management to the Justice Ministry. Even so, the army continued to supply the island's troops and commanders (renamed "directors" after 1877). In 1882, 285 inmates convicted by military tribunals and 231 slave convicts lived alongside 1,045 free civilian convicts. Of 1,561 convicts, only thirty were women. Some 7 percent of inmates were foreign-born (mostly African or Portuguese), and the rest came from almost every Brazilian province; hence the island's reputation as Brazil's "central deposit for civilian convicts." 22 Most inmates were homicide convicts, but a minority of thieves, "deflowerers," or counterfeiters, and recidivist army deserters also did time there. With the exception of a few political prisoners and counterfeiters, most convicts were poor, illiterate men who worked in agriculture and urban manual labor. ${ }^{23}$

20 Rufino Augusto de Almeida, Estado actual das prisões da província de Pernambuco (Recife: Typ. De M. Figeroa, 1874), 11, 40-41; Antonio Herculano de Souza Bandeira Filho, Informações sobre o presidio de Fernando de Noronha (Rio: Imprensa Nacional, 1880), 32-33.

21 Instituto Brasileiro de Geografia e Estatística [IBGE], Estatísticas históricas do Brasil, 2d ed. (Rio: IBGE, 1990), 31-33.

22 Bandeira, Informações, 18; Conselheiro André Augusto de Padua Fleury, Parecer sobre o Presídio de Fernando de Nornoha (Rio: Imprensa Nacional, 1880), 5. Peter M. Beattie, “"Born under the Cruel Rigor of Captivity, the Supplicant Left It Unexpectedly by Committing a Crime': Categorizing and Punishing Slave Convicts in Brazil, 1830-1897," The Americas 66, 1 (July 2009): 11-54; Relatorio ... Justiça, Conselheiro João Ferreira de Moura (Rio: Typ. Nacional, 1883), 142-43.

23 Relatorio, Fernando de Noronha, 1 Jan. 1876, APPJE, FN-17, f. 145-79; ibid., 1 Jan. 1877, FN-18, f. 300; Bandeira, Informações, 35. 
TABLE 1.

Color of Convicts on Fernando de Noronha; Matriculation and Guia Records, 1830s, $1850 s-1880 s$.

\begin{tabular}{lcr}
\hline \hline Color & Number & Percent \\
\hline Dark Brown & 413 & 41.0 \\
Black & 267 & 26.6 \\
White & 196 & 19.6 \\
Light Brown & 67 & 6.7 \\
Indigenous & 54 & 5.4 \\
Cafuz & 7 & 0.7 \\
& 1004 & 100.0 \\
\hline \hline
\end{tabular}

Cafuz describes an individual of African and Indigenous heritage. Sources: Livro de guias, Serie Justiça, Código do Fundo ND, Seção de Guarda Codes, Fernando de Noronha, 1829-1837, Arquivo Nacional do Rio de Janeiro (hereafter ANR), IIJ 7 91, and ibid., 1853-1861, IIJ 7 2; Livro da matricula ... 11 de Fevereiro de 1865, Fernando de Noronha, ANR, Seção de Justiça, livro IIJ 7 94; Livro da matricula ... 10 de Janeiro de 1885, ibid., livro IIJ 76.

The army garrison was too small to police convicts who often outnumbered them ten to one, a situation that led one officer to depict them as a "dike set against a sea of a thousand passions." Another described his troops as "crapulous and undisciplined.... Instead of sending soldiers with good discipline, they send soldiers with a propensity for heavy drinking, disorders, and incorrigible behavior... Military convicts who complete their sentences are reassigned as part of the [penal colony's] army detachment." Officers worried that soldiers fraternizing with convicts would form a common cause; concurrently, they feared that guards would exploit convicts and unleash conflicts. In short, officers had to worry about maintaining order among their troops as much as among the inmates. In 1854, a commander reported a plot to surprise the army detachment during mass and "immolate unfailingly the officers and employees along with their innocent families." 24 Similar alleged plots surfaced regularly. An inspector observed in 1879: "The commanders procure among the prisoners the guarantees that the army forces should give them.... There are prisoners who are publicly known as the commander's enemies ... that do not hide their ill will; others support the commander and both factions try to attract followers. This is what they call political parties (partidos)."25

Officers not only had to win the support of many convicts, but they also had to motivate them to work. To do so, they organized labor gangs into military

\footnotetext{
24 Tenente Coronel José Antonio Pinto ao José Bento da Cunha Figueredo, 29 Jan. 1854, APEJE, FN-6, f. 26.

25 Relatorio, 1 Jan. 1877, APPJE, FN-18, f. 300; Bandeira, Informações, 36.
} 
companies. While two civilian employees headed convict work "companies" in 1879 , warders named trusted convicts to "sergeant" the remaining thirteen. Sergeants flanked by two convict corporals led work regiments of 90 to 160 inmates. One convict company served as an auxiliary police force, but most tended fields or cattle and others worked as cobblers, artisans, domestics, fisherman, and scriveners. Female convicts performed "work inherent to their sex": laundry and domestic service. Officers, employees, and even convict sergeants retained inmates as domestics. Perhaps more than anything, the colony resembled an exceptionally large and isolated plantation. In bountiful years it exported sea-island cotton, corn, manioc, and boots, but it depended on the regular importation of food.

Since most commanders were or had been commissioned army officers, they drew on their experience of managing unruly soldiers. Most were also familiar with slavery and frontiers. ${ }^{26}$ Brigadeiro Henrique Pedro Carlos de Beaurepaire Rohan, who authored Fernando de Noronha's first regulations in 1865, had such experience. An army engineer who had built roads into São Paulo's interior, Rohan became a Liberal Party politician and served stints as a provincial governor and war minister. He was also a noted cartographer who published reflections on his travels, which included a polemic against Francisco Adolfo de Varnhagen's condemnation of Indians. In this 1854 essay, Rohan argued that Indians could contribute to imperial society if properly assimilated, but he belittled the state's use of Capuchin monks (barbadinhos) to civilize frontier Indians: "The barbadinho's understanding that he is thoroughly fulfilling his mission by preaching fasting and chastity to these people!" Rohan authored a parliamentary report about Fernando de Noronha in 1865 in which he explained why he favored the formation of frontier penal colonies where convicts would live with their families over urban penitentiaries: first, Brazil should increase its population and occupy its frontiers; second, the family's presence deterred escapes; and third, "why should one condemn these men to immoral celibacy?" Like many of his contemporaries, Rohan adopted Argentine Juan Alberdi's belief: "To govern is to populate." But unlike Alberdi, Rohan did not feel this population had to be European to civilize the frontier; it could include multiracial convicts and assimilated Indians. ${ }^{27}$

Rohan spent years in isolated outposts and urban centers managing regular enlisted men. Authorities dragooned most regulars as a punishment for vagrancy, suspected criminal activity, or because they had abandoned their wives or seduced young women with false marriage promises. Marriage, however, exempted poor free men from impressment if they "protected" and

${ }^{26}$ Relatorio ... Justiça, Lafayette Rodrigues Pereira (Rio: Typ. Preseverança, 1878), 93; Bandeira, Informações, 35.

${ }^{27}$ Rohan, "A ilha," 30; idem., "Considerações acerca da conquista, catechese e civilisação dos selvagens do Brasil,” Guanabara (Rio, 1854), II, 191-92 (my emphasis). 
provided for wives and dependents. Floggings, roll calls, mobility restrictions, batch living, and displays of subordination made soldiering appear close to slave status for many free men. Indeed, the status of soldiering was so low that attempts to use a color bar to exclude or segregate men of African descent had been abandoned by the 1850s. Like convicts, most soldiers were of mixed racial heritage and served alongside minorities of whites, blacks, former slaves, and a few indigenous men. ${ }^{28}$

How did officers control this motley crew of mostly bachelors? Beyond flogging and drills, they rewarded dutiful soldiers with the right to desarranchar: to live off base and receive a per diem. Commanders could also grant these soldiers the right to marry or to live with a consensual lover. If they became disobedient or failed to act as responsible household heads, officers ordered them to arranchar: return to live and dine in the barrack rancho (mess hall). Officers even managed the sexuality of batch-living soldiers. A 1906 medical thesis reported that "sodomy" had been common in the army during the empire (1822-1889), but that by tolerating feminine prostitution around bases, Republican officials had nearly eliminated same-sex eroticism in the barracks. ${ }^{29}$

Officers' strategies paralleled those of slave owners who also faced the challenge of disciplining and motivating workers that they typified as intractable. Masters often housed slaves in gender-segregated senzalas, but recent research demonstrates that formal slave marriage rates in southeastern Brazilian communities were as high as 25 to 40 percent, although fewer slaves married in the northeast. Revisionists observe that slaves with access to provision grounds and a private abode were more likely to be married or form consensual unions. Of course, there were limits on slave husbands' rights. Legal opinions clarified that they could only exercise pátrio poder to the extent a master allowed, but Catholicism (unlike Protestantism) supported a slave's right to the sacraments, including marriage. ${ }^{30}$ Anglophone masters opposed formal slave marriage because it implicitly ceded freedom of contract and patriarchal power to slaves, which raised the specter of competing systems of authority. They also argued that slave marriage sullied the institution because slaves had no honor. Moreover, Anglophone laws in the North American mainland often barred interracial marriage between free persons, which differed markedly from independent Brazil where no such ban existed, and from more flexible practices in the British Caribbean and colonial Cuba. Indeed, the Brazilian elite came to embrace miscegenation as a means to "whiten" its diverse

${ }^{28}$ Peter M. Beattie, The Tribute of Blood: Army, Honor, Race and Nation in Brazil 1864-1945 (Durham: Duke University Press, 2001).

29 José Ricardo Pires de Almeida, Homosexualismo (a libertinagem no Rio de Janeiro) (Rio: Laemmert, 1906), 76-85.

${ }^{30}$ [Agostinho Marques] Perdigão Malheiro, A escravidão no Brasil: ensaio histórico, jurídico, social, 2 vols., 3d ed. [1st ed. 1867-1869] (Petropolis: Vozes, 1976), I, 17-75, 95, 181-83; II, 123-24. 
population. These cultural contrasts were shaped by divergent religious and cultural sensibilities about slave and interracial marriage and different ideals of male sexual prerogatives. ${ }^{31}$

Why did Brazilian masters allow slaves to marry? Robert Slenes cites a daughter's recollection of her slave-owning father's statement: "It is necessary to marry this slave and give him a piece of land so that he learns judgment (tomar juizo)." Slenes argues that by allowing some slaves to leave the senzala's batch living, wed, and work a provision ground, some masters hoped to stem desertion and promote productivity, discipline, and morality in a way similar to permitting soldiers to desarranchar. Slenes' data comes largely from core plantation zones, but these practices were not limited to rural or frontier areas, and extended to slaves and soldiers located in cities. As Jean Batiste Debret noted, "In the houses of Brazil's wealthy, they marry their female slaves without contradicting too much their predilections in the choice of a husband [usually a male slave of the same household]; this custom springs from the hope of better tying them (prendê-los) to the house."32

Penal colony officers used similar strategies with convicts. Jeremy Bentham's ideal of cellular isolation was virtually absent on Fernando de Noronha, and was limited to two small lockups in the building known as the "Aldeia" (village) and the main fort. In addition to small jail cells, the Aldeia's main rooms warehoused four hundred "miserable" prisoners. In 1876, a commander described the Aldeia as "the dormitory for bachelor convicts (solteiros), those who are incorrigible, and those who are incarcerated."33 While commanders granted many bachelor convicts the right to live outside the Aldeia, they continued to associate the building with bachelors, and women convicts were not held there. Like most male convicts, women lived either in

31 See, e.g., John Bailey, The Lost German Slave Girl (New York: Atlantic Monthly Press, 2003), 99-100; Barbara Bush, Slave Women in Caribbean Society 1650-1838 (Bloomington: University of Indiana Press, 1990), 98-103; Cecilia A. Green, “'A Civil Inconvenience’? The Vexed Question of Slave Marriage in the British West Indies, Law and History Review 25, 1 (Spring 2007): 1-60; Verena Martinez-Alier, Marriage, Class and Colour in Nineteenth-Century Cuba: A Study of Racial Attitudes and Sexual Values in a Slave Society, 2d ed. (London: Cambridge University Press, 1974); Thomas Skidmore, Black into White: Race and Nationality in Brazilian Thought (London: Oxford, 1974).

32 Robert W. Slenes, Na Senzala uma flor: Esperanças e recordações da família escravaBrasil, sudeste século XIX (Rio: Nova Fronteira, 1999), 86, 148-80, 188; Debret, Viagem pitoresca e histórica ao Brasil, 2 vols. (São Paulo: Livraria Martins, 1940), II, 180-81; Manolo Florentino, $A$ Paz das senzalas: famílias escravas e trafico atlântico, Rio de Janeiro, c. 1790-c. 1850 ( Rio: Civilização Brasileira 1997), 147-78; Hebe Maria Mattos, Das cores do silêncio: Os significados de liberdade no sudeste escravista-Brasil século XIX, 2d ed. (Rio: Nova Fronteira, 1995); Sheila de Castro Faria, "Família, escrava e legitimidade: estratégias de preservação da autonomia," Estudos Afro-Asiáticos 23 (1992): 113-31; B. J. Barickman, "A Bit of Land, which They Call 'Roça': Slave Provision Grounds in the Bahian Recôncavo, 1780-1860," Hispanic American Historical Review 74, 4 (Nov. 1994): 649-87; Stuart B. Schwartz, Sugar Plantations in the Formation of Brazilian Society: Bahia 1550-1835 (New York: Cambridge University Press, 1985), 382-94.

33 Fleury, Parecer sobre, 6; Relação, 1 Jan. 1876, APPJE, FN-17, f. 145-79. 
superiors' homes or in huts that they constructed or purchased. Most convict homes stood in proximity to the square of the town of Remédios, where the commander's home and offices were. ${ }^{34}$

An American journalist who visited Fernando de Noronha in the 1870 s confirmed that married convicts enjoyed privileges: "As a rule, the convicts spend half of their exile in prison [the Aldeia]. If well-behaved, they may afterward live outside, build their own hut and cultivate their own garden, Government giving all, whether in prison [the Aldeia] or out of it, a certain allowance of food. If specially [sic] well-behaved, particularly if married, they may sooner live outside, a boon granted by the Governor on application. A married convict can insist on having his wife and children beside him; and, though free, they often come from the Brazils [sic] to share a husband's or father's exile." 35 This depiction was not entirely accurate. Only a few men in the Aldeia were "incarcerated," and most used it as a dormitory that closed at 6:00 P.M. and reopened at 6:00 A.M. The Aldeia resembled the batch living of barracks and senzalas. By the 1860s, when the convict population surpassed fifteen hundred, it was impossible for convicts to spend half their sentences in the Aldeia, given its limited capacity. As one inspector reported: "The recently arrived accommodate themselves as they can, making their residences where they can," but if they became incorrigible, they could be ordered to sleep in the Aldeia. Married convicts with family did sooner establish a private home and gained access to a garden, but disciplined bachelor convicts could earn similar privileges. Even with a provision ground, married convicts lived miserably because they earned the same meager wages and rations as bachelors. Commanders probably favored married convicts with higher-paying positions, like company sergeant, to help them support their families. ${ }^{36}$ Data from an 1891 report enumerated 383 married convicts and 112 convict wives. Many wives joined married convicts in penal exile, though a minority of them had wed after arriving in the colony. In 1891, nearly one in ten inmates lived with a wife and less than half that many (forty-four) lived with a consensual lover (amaziado). As with convicts, authorities permitted some army guards to bring wives and consensual partners with them, and many officers, employees, and vendors brought their families, too. ${ }^{37}$

Despite the social and institutional pressures to wed, many free mainland Brazilians chose not to. Many preferred to live as consensual partners and practiced serial monogamy. In the interior clergy were scarce and many couples

\footnotetext{
34 Bandeira, Informações, 27; Michel Foucault, Discipline and Punish: The Birth of the Prison, Alan Sheridan, trans. (New York: Pantheon Books, 1977), 135-230.

35 "Fernando Noronha: The Penal Settlement of Brazil," Scribner's Monthly (Feb. 1876): 538-39.

36 Bandeira, Informações, 33, 37, 41.

37 Relatorio ... Gusmão Coelho, ibid., f. 2. In 1876, one in fifteen convicts (97 of 1,531) lived with wives, and forty-one with "amazias." Relação, 1 Jan. 1876, APPJE, FN-17, f. 145-79.
} 
TABLE 2 .

Population on Fernando de Noronha.

\begin{tabular}{lrrrrr}
\hline \hline Year & 1852 & 1858 & 1869 & 1874 & 1886 \\
\hline Employees and Officers & 12 & 15 & 17 & 12 & 16 \\
Family & 52 & 290 & 49 & 26 & 60 \\
Army troops & 98 & 182 & 200 & 126 & 175 \\
Family & 2 & & 9 & 27 & 74 \\
Civil Convicts & 305 & 630 & 1,010 & 1,441 & 1,216 \\
Family & 87 & & 278 & 241 & 500 \\
Military Convicts & & 33 & 242 & 234 & 251 \\
Family & & & 9 & & \\
Vendors & & & 13 & 11 & \\
Family & 52 & & 9 & 7 & \\
Unrelated residents (avulsos) & 37 & & 49 & 59 & \\
Family & 2 & 0 & 0 & 27 & 19 \\
Others & 10 & 0 & 0 & 59 & 24 \\
Family & 0 & 10 & 12 & 11 & 3 \\
Slaves & 657 & 1,133 & 1,953 & 2,332 & 2,338 \\
Total & & & & &
\end{tabular}

Empty cells indicate that no information is available for that year. In most years, military convicts' family were subsumed under convict families, and in 1858, it appears that all families were grouped with employees and officers. Sources: Alferes Raimundo José de Souza Lobo, 1 July 1852, APEJE, FN-4e, f. 106; AGL ao BAMJ, ibid., 18 Feb. 1858, FN-7, f. 21; Relatorio de Francisco Joaquim Pereira Lobo, ibid., 1 Jan. 1869, FN-13, f. 1-17; Relatorio, ibid., 1 Jan. 1874, FN-16, f. 182-98; Relatorio Manoel Gonsalves Pereira Lima, Ibid., 1 Jan. 1886, FN-24, f. 2.

there lived together on the basis of a marriage promise. Consensual conjugality was common, and if a couple lived respectfully together, most viewed their union as worthy of repute, though it did not confer the legal protections, privileges, and responsibilities of formal marriage. There are no broad surveys of marriage rates in nineteenth-century Brazil, but other data offer proxy measures. Based on the 1870 household census of Rio's São Cristóvão neighborhood, Elizabeth Kuznesof estimates that as many as 85 percent of children lived in a two-parent household, but she could not distinguish between those in formal and informal unions. ${ }^{38}$ Silvia Maria Jardim Brügger finds that rates of

38 Borges, The Family, 46-47, 247-48; Elizabeth Anne Kuznesof, "Sexual Politics, Race, and Bastard-Bearing in Nineteenth-Century Brazil: A Question of Power or Culture?" Journal of Family History 16, 3 (1991): 241-60; idem., "Who Were the Families of 'Natural' Born Children in Nineteenth-Century Rio de Janeiro Brazil: A Comparison of Baptismal and Census Records," The History of the Family 2, 2 (1997): 171-82; Donald Ramos, "União consensual e a família no século XIX: Minas Gerais, Brasil," Estudo Econômicos 20, 3 (1990): 381-405; idem., "From Minho to Minas: The Portuguese Roots of the Mineiro Family" Hispanic American Historical Review 73, 4 (Nov. 1993): 639-62. 
TABLE 3.

Fernando de Noronha: Convict Color, Condition, and Marital Status.

\begin{tabular}{lcccc}
\hline \hline & Single & Married & Widowed & Total \\
\hline Color & & & & \\
Black & $167(75.6 \%)$ & $46(20.8 \%)$ & $8(3.6 \%)$ & $221(100 \%)$ \\
Brown & $148(51.6 \%)$ & $109(38 \%)$ & $30(10.4 \%)$ & $287(100 \%)$ \\
White & $47(34.3 \%)$ & $71(51.8 \%)$ & $19(13.9 \%)$ & $137(100 \%)$ \\
Legal Status & & & & \\
1-Slave & $164(82.8 \%)$ & $31(15.7 \%)$ & $3(1.5 \%)$ & $198(100 \%)$ \\
2-Free & $213(36.5 \%)$ & $291(49.8 \%)$ & $80(13.7 \%)$ & $584(100 \%)$ \\
3-Soldier & $147(87 \%)$ & $18(10.7 \%)$ & $4(2.3 \%)$ & $169(100 \%)$ \\
\hline \hline
\end{tabular}

legitimacy in the 1850s for free born women in São João del Rei, in Minas Gerais, were 67.73 percent, 40 percent for manumitted women, and 14.29 percent for slave women. The 1890 census gives an imperfect gauge of rising marriage rates in its statement that 81 percent of births were legitimate. ${ }^{39}$

Table 3 breaks down the marital status of prisoners by legal condition and color. The data indicates that marital status mirrored mainland social and color hierarchies, where whites and free citizens were more likely to marry than non-whites, slaves, and soldiers. In this sample, browns were almost twice as likely to marry as blacks, though more slave convicts married than did soldiers. The high percentage of convicts who were betrothed indicates that despite the expectations of officials marriage had not acted as an effective brake on crime. Indeed, the percentage of married convicts, even among slaves, may have been higher than in the general population. Since most convicts were sentenced for homicide, it is possible that marriage encouraged violence in defense of marital honor, but the evidence here is little more than suggestive.

Barracks, senzalas, and the Aldeia segregated mostly unmarried men into batch living quarters. The right to live in separate quarters and to marry or live with a consensual lover was a bargaining chip that masters and officers used to reward collaboration and raise the stakes for unruliness, sloth, or desertion. Commanders often referred to married convicts as elements of order in the colony. However, what powerful actors saw as privileges that served as

\footnotetext{
39 Silvia Maria Jardim Brügger, "Legitmidade, casamento, e relações ditas ilícitas em São João del Rei (1730-1850)," IX Seminário Sobre a Economia Mineira, 48. In Minas, 85 percent of births were classed as legitimate in 1890, whereas in 1844 only 65 percent were. Falla dirigida á Assembléa Legislativa Provincial de Minas Geraes na sessão ordinaria do anno de 1846, pelo presidente da provincia, Quintiliano José da Silva (Ouro Preto: Typ. Imparcial de B. X. Pinto de Sousa, 1846), 124, graph 18; Data organized by Sandra Lauderdale Graham confirms this trend, in House and Street: The Domestic World of Servants and Masters in Nineteenth-Century Rio de Janeiro (London: Cambridge University Press, 1988), 192.
} 
incentives for good behavior, slaves, enlisted men, and convicts often came to see as rights.

The faith that many Brazilians had in the nuclear family as an element of social order is hard to exaggerate, and many authorities faced a dilemma when sentencing married men. Ideally, a poor male patriarch would provide for and protect his wife, dependents, and himself from the sexual aggressions of other males. By jailing husbands, authorities removed the natural male "protector," and many evinced the fear that this would force a convict's wife and daughters into prostitution. The same fear led officials to exempt married men from military impressment. Authorities worried that convicts' wives and children could unjustly be punished for the crimes of their household head and create new social burdens. As Rohan put it, "While their women, abandoned on the mainland, procure, for themselves and their children, resources in prostitution (devassidão), their husbands, isolated in the presidio, deliver themselves over to the most degrading perversions (desvios), from which originate the only illnesses [venereal diseases] known on this blessed island. ${ }^{40} \mathrm{He}$ ignored that many women headed households and lived without a husband or lover to protect them without turning to prostitution. ${ }^{41}$ Even so, the idea of unprotected women's vulnerability remained a powerful trope that complemented common interpretations of male sexuality. The chief of Recife's penitentiary bragged that when he had temporarily organized remunerated work for prisoners, "many inmates could provide some support to their wives and daughters who were ready to throw themselves into prostitution's abyss." 42

Rohan's 1865 penal colony regulations provided a piecemeal solution to spousal separation and the unrelenting male sex drive. While some convict wives had been present on the island before 1865, Rohan's rules facilitated conjugal penal living, and the number of convict families increased. ${ }^{43}$ His solution also made sense to other commanders. As one wrote in 1870:

The union of the sexes being a law of necessity created and imposed by nature, it is manifest that ... the women ... constitute an element of order and morality on this island ... because when each convict finds in his partner the satisfaction of this imperious necessity, they will cease to scheme to conquer the wives of other men, which has

${ }^{40}$ Rohan, “A Ilha," 29.

${ }^{41}$ Kuznesof, "Who Were the Families," 171-82; B. J. Barickman, "Reading the 1835 Parish Census from Bahia: Citizenship, Kinship, Slavery, and Household in Early Nineteenth-Century Brazil," The Americas 59, 3 (Jan. 2003): 287-324; Sandra Lauderdale Graham, "Honor among Slaves," in Sonya Lipsett-Rivera and Lyman L. Johnson, eds., The Faces of Honor: Sex, Shame, and Violence in Colonial Latin America (Albuquerque: University of New Mexico Press, 1998), 221-28; Maciel Henrique Silva, "Delindra Maria de Pinho: Uma preta forra de honra no Recife da primeira metade do século XIX," Afro-Asia 32 (2005): 219-40.

${ }^{42}$ Rufino Augusto de Almeida, Estado actual das prisões da província de Pernambuco (Recife: Typ. De M. Figeroa, 1874), 7.

${ }_{43}$ Marcos Paulo Pedrosa Costa, O caos resurgirá da ordem: Fernando de Noronha e a reforma prisional do império (São Paulo: IBCCRIM, 2009), 159-71. 
caused disturbances in the past. This is an element of morality because the presence of women will naturally cause the abominable sin of sodomy to disappear; it is unfortunate and embarrassing, but sodomy is a widespread practice here. Beyond this, experience in this presidio has shown that a woman has the great advantage of awakening ... the love of work [in men] because of the need to duplicate his exertions to support his partner ... transforming imbecilic and lazy men into hard-working, intelligent, and dedicated laborers.

He then cited his predecessor's aphorism: "Without women it is impossible to govern Fernando de Noronha." 44

Other officials had taken this logic further. Rohan reported that Pernambuco's police chief had sent thirty "girls" (raparigas) to marry bachelor convicts to "moralize" the island. Rohan likely felt he was building on precedent. Eighty marriages occurred between convicts and unattached women on the island from 1865 to $1879 .^{45}$

Few criticized Rohan's policy. An exception was the administrator of Recife's penitentiary Rufino Augusto de Almeida who, in 1874, referenced Lombroso to censure those who had sent women to the colony:

Is it right to send to that presidio a great number of women recruited from brothels to there unite them, not by the ties of the heart, but by sensuality, with beings as depraved, if not more so, than they are? I say 'recruited' from brothels because I do not believe that one will find in our society even the most miserable women willing to marry convicts.... If vice-ridden men, inheritors of base instincts, procreate with women of sound health and spirit, they produce children that inherit all of their father's physical and moral defects, what should one expect from a marriage in which both partners are equally infirm? ${ }^{46}$

Even more exceptionally, Almeida added: "I do not agree with the opinion of those who judge conjugal life necessary for a prisoner's physical and moral health.... This question is no longer discussed among the men of penitentiary science. Society is not obligated to sustain a criminal's family."47 Here, Almeida backs an individualistic, liberal view of punishment and observes that European prisons did not even allow conjugal visits (which were innovations of the Mexican and Russian revolutions). ${ }^{48}$ Indeed, liberal penal codes like Brazil's had repealed dishonoring, ancien regime punishments of a convict's family. The preoccupation of Brazilian authorities with the impact of married men's incarceration on their wives seems exceptional, but the subject requires further comparative investigation. ${ }^{49}$ While Almeida noted that philanthropic societies should help convict families, he rejected

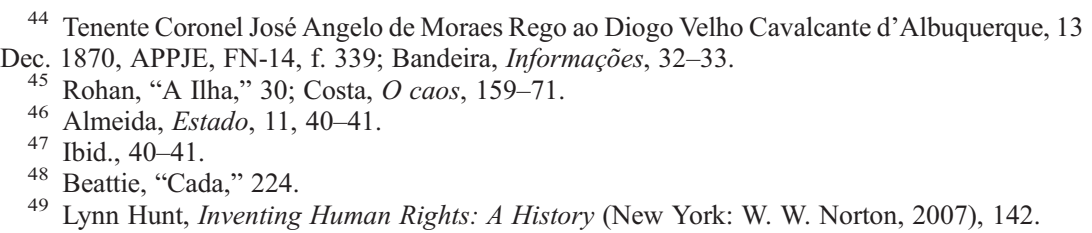


arguments that men required conjugal life and heterosexual sex for their health. Despite his critiques, he admitted that conjugal living could be rehabilitative if the government built a prison with eight hundred individual cells to isolate men at night on the island: "[Through] his good conduct and love of work, he can reside outside the prison in the company of his family, which will produce beneficial effects and bring him to a sincere atonement that will result in moral regeneration." Any infractions, Almeida said, would require him to return to cellular isolation. War and Justice Ministry reports echoed his call for construction of such prisons, but Parliament never heeded them. ${ }^{50}$ In the end, even those who challenged articles of faith in the jealous institution argued that it would work if correctly regulated.

DISORDER AND REASSESSMENTS OF ROHAN'S POLICY

An 1876 uprising on Fernando de Noronha likely contributed to Parliament's decision to transfer its administration to the Justice Ministry. For three days garrison soldiers brawled with convicts in Remédios. The rebellious troops refused to obey their officers, and a series of rumbles left many injured and one convict dead. Luckily for the commander, an imperial navy vessel was in port and with the support of marines and loyal convicts he convinced the mutineers to surrender. A Rio newspaper cartoon lampooned the incident: "On Fernando de Noronha, it is no longer the soldiers who guard the prisoners, but the prisoners who maintain order disrupted by soldiers." 51

The new commander's arrival did not resolve simmering tensions. An anonymous 1877 letter excoriated the new commander and his predecessor: "The current commander took control of the island, anxious to give vent to his pliable nature, much like his predecessor, that well-known favorite of a certain descendant of the race of Sodom." The scabrous missive claimed that the commander conspired with a group of convicts to skim money from the penal colony's population. It also accused him of the impropriety of fraternizing with convict families. ${ }^{52}$ It alleged that he invented excuses "for bringing families together for a dance which does not look good for a single man.... Convict families socializing with the commander!" The letter confirms that convict families enjoyed higher status and closer approximation to officials. It is not possible to verify the truth of the allegations, and the commander forcefully denied them in a letter of his own. ${ }^{53}$

Who wrote such a letter? Commanders fumed that convicts freely corresponded with the mainland where the opposition press seized upon their

\footnotetext{
50 Almeida, Estado, 40-41; Relatorio ... Justiça, Dr. Francisco d'Assis Rosa e Silva (Rio: Imprensa Nacional, 1889), 128-29.

51 Revista Illustrada, Rio, 13 Jan. 1877; José Bonifácio dos Santos Mergulhão ao Manoel Clementino Carneiro da Cunha, 24 Dec. 1876, APPJE, FN-17, f. 278.

52 Bandeira, Informações, 35.

53 Observador, Carta Anomyna [sic], 6 Apr 1877, ANR, IG-85, no f. nos.
} 
allegations. Civilian employees and garrison officers could also spread rumors since they were often at odds with one another. A Justice Ministry inspector opined that convicts abused correspondence to spread canards. Whoever the author of this particular letter was, he sought to discredit the incumbents' authority. Whether moved by these events or not, Parliament, in what a justice minister later referred to as a "laconic disposition that was only explicit in decreeing the transfer," shifted the colony's administration on 20 October 1877. This prompted new officials to reassess Rohan's regulations. ${ }^{54}$

In 1879, the inspectors Conselheiro André Augusto de Padua Fleury and Dr. Antonio Herculano de Souza Bandeira Filho arrived on the island, determined to put a civilian stamp on the colony. Fleury would in 1883 be named director of São Paulo's Law School, and in 1885 be elected as an imperial deputy for his home province of Mato Grosso. Bandeira was born in Recife and worked as a lawyer, diplomat, and essayist. Both men had traveled to Europe to study prisons. The Justice Ministry charged these well-educated men to propose reforms, and to these outsiders, life in the colony was a bagaceira: the loose moral environment allegedly characteristic of the sugar plantation's mill. They attributed much of the colony's lax discipline and dissolution to excessive leisure, because most convicts only worked from 9:00 A.M. to 2:00 P.M. daily. To the inspectors' horror, even slave convicts had time on their hands. ${ }^{55}$

They also questioned the wisdom of women and children's presence in the colony. Fleury relates, "Prostitution had assumed frightening proportions. There are girls of eight and nine years of age who are already perverted and depraved with the knowledge and approval of their parents. Convicts often seek to marry for ignoble ends, to the point that husbands encourage their wife's infidelity in order to profit." ${ }^{, 56}$ These inmate husbands subverted the jealous institution and failed to behave in the way officials asserted they "naturally" would.

Bandeira recommended the removal of female convicts and argued against the logic that more women would benefit morality: "Experience proves the contrary; when one allows, without discrimination, convicts to live with women, morality will not be possible and one can expect the increase of vice on the island." 57 He condemned the "independent women" who lived in the colony, and recommended that only women connected to convicts who had proven their good behavior be allowed to stay. Fleury wrote that with very few

${ }^{54}$ Relatorio ... Justiça, Conselheiro João Ferreira de Moura, 140; Fleury, Parecer sobre, 7; Bandeira, Informações, 12, 29; The War Ministry favored the colony's transfer to the Justice Ministry because most convicts there were civilians. Relatorio ... guerra, Duque de Caxias (Rio: Typ. F. Paulo Hildebrandt, 1877), 18; ibid., Relatorio ... guerra, Affonso Augusto Moreira Penna, 173; Beattie, "Born," 11-54.

55 Fleury, Parecer sobre, 7, 15.

56 Ibid., 8 .

57 Bandeira, Informações, 34. 
exceptions there were "no honest women in that place," and like Almeida, he decried officials who had sent women to the colony from the "dregs of society," already corrupted by vice. ${ }^{58}$

Bandeira blamed women's presence for "causing constant disturbances and atrocious crimes," and there was evidence to support his assertion. For instance, on 9 September 1876, the convict soldier Affonzo Ribeiro de Lima stabbed Maria Agostinha da Conceição to death. The commander wrote that his motive was "without a doubt because of his miserable unrequited sexual passion for her." He added that the killer was age twenty-five, but that he had already committed two murders since his original homicide conviction. ${ }^{59}$

Despite such incidents, Bandeira demonstrated the enduring faith in the jealous institution by citing one commander: "If it is true that unmarried women have been at times the motive for conflicts between prisoners, it is not entirely due to the presence of women in the presidio, but only to their small number, that awakens in all the desire to possess them and has been the origin of a few disturbances, that without a doubt would tend to disappear if measures were taken to augment their numbers. ${ }^{60}$ According to this logic, women's moralizing influence simply required greater gender balance, but the inspectors had their doubts.

Like Almeida, however, the inspectors did not ultimately reject the idea that women could encourage morality. They seemed preoccupied with women's morality and less interested in same-sex eroticism. Like others of their era, they may have ascribed to the view that once a woman had been sexually "tainted," she would corrupt "honest" women with whom she came into contact. Bandeira worried about the exposure of convict, vendor, soldier, and employee families to the island's bagaceira, which contradicted Fleury's assertion that there were almost "no honest women."61

Convict women's "liberty" vexed inspectors. Most worked in the infirmary's laundry, but these duties were not onerous, and many allegedly occupied their free hours prostituting themselves, a fact that Bandeira wryly noted was the "only way they fulfilled their sentences." If women were necessary to govern Fernando de Noronha, then they had to have their liberty curtailed. ${ }^{62}$ The inspectors recommended removing women convicts and some nine hundred male convicts whose sentences did not technically qualify them for admission to Fernando de Noronha. This proposal was rejected because Pernambuco's

58 Ibid., 32-34; Fleury, Parecer sobre, 8.

59 Major José Bonifácio dos Santos Mergulhão ao Manoel Clementino Carneiro da Cunha, 20 Sept. 1876, APPJE, FN-17, f. 209-10.

60 Bandeira, Informações, 32-33.

61 Windler, "City of Children," 106-7; Fleury, Parecer sobre, 8; Bandeira, Informações, 34.

62 Bandeira, Informações, 32; Captain Antônio Francisco de Costa ao Luis Corrêa de Queiroz Barros, 17 Oct. 1885, APPJE, FN-24, no f. nos. 
governor complained that he had no prison capacity to hold large number of convicts while courts decided their fates. ${ }^{63}$

\section{POLICING FAMILY HONOR}

Justice Ministry inspectors did not recognize the efforts of commanders to police convict family honor. Officers wrote wistfully of the "honest" wives of convicts and soldiers who deserved respect, as well as good husbands and fathers of family. Fleury's perception that there were almost no honest women may have reflected the different experiences of elite law school graduates versus military officers who worked daily with the intractable poor. Where inspectors saw an undifferentiated group of dishonored men and women, officers may have seen status distinctions in which marriage and conjugal living marked thresholds of status. ${ }^{64}$ This section explores commanders' efforts to police family honor and how convicts and their dependents responded to them.

The growing number of women had unintended consequences that Rohan's regulations failed to anticipate. In 1866, a commander protested that the widows of convicts who died on the island and their dependents could not pay for their passage back to the mainland. Similarly, when authorities returned married convicts who had finished temporary sentences to the mainland they had no funds to pay for their wives' and dependents' passage. Unless they could pay their own way, they remained and became "subject to prostitution and misery." 65 This problem was never fully resolved. In 1888, the director justified paying the passages of a convict's wife, daughter, and son to Recife to "prevent a crime." He explained that the husband had returned to the mainland but his dependents remained. If they stayed, the women would have to "give themselves over to prostitution" to survive, and then he would have to pay "to send them back to Recife for incorrigible behavior" anyway. ${ }^{66}$ Another commander returned a convict wife to the mainland months after her husband had abandoned her. He explained that he had not sent her away earlier because "she had always behaved well," but changed his mind when he learned that her husband had allegedly decided to prostitute or "market" her. 67

Commanders used methods similar to those employed on the mainland to defend family propriety. When a convict seduced the fourteen-year-old

63 Relatorio ... Justiça, Manoel Pinto de Souza Dantas (Rio: Imprensa Nacional, 1882), 157; Relatorio ... Justiça, Samuel Wallace MacDowell (Rio: Imprensa Nacional, 1887), 160.

${ }_{64}$ Bandeira complains that commanders had no knowledge of penology; Informações, 16.

65 Quartel Commando do Presídio, 25 Aug. 1866, APPJE, FN-12, no f. nos.

66 Francisco Joaquim Pereira Lobo ao João Rodrigues Chaves, 20 May 1885, APPJE, FN-24, no f. nos.; Also, Antonio de Campos Mello ao Henrique Pereira de Lucena, ibid., 8 July 1873, FN-16, f. 146; Sebastião Antonio do Rego Barros ao Francisco d'Assis Pereira Rocha; ibid., 12 July 1870, FN-14, f. 271.

67 J. dos Passos Queiroz ao Innocencio Marques d'Araujo Goes, n.d., APPJE, FN-28, f. 249. 
daughter of another inmate, her father put her on deposit in an inmate sergeant's house, "a married man that lives his life honestly." The commander ordered the offender jailed, and found that he had seduced the girl with "frivolous promises." The parents opposed their daughter's marriage to such a man of "bad character and insolence." Meanwhile, another inmate offered to marry her and repair her honor. The parents and the girl accepted, and after the priest confirmed that there were no impediments, the couple wed. ${ }^{68}$

Soldier's wives and lovers also caused scandal. A commander complained in 1884:

Article 70 of the Regulations ... authorizes me to expel any woman who behaves scandalously. But the inmates and soldiers that are sent to fulfill their sentences and those soldiers sent here to serve in the garrison bring their families composed many times of wife, children, mother, and siblings, besides others who obtain permission from the governor to bring along their lovers. These women after some time in residence in this presidio unfortunately throw themselves into the life of prostitution [and] have obliged me ... to expel them ... at government expense to avoid disorders and crimes that have occurred in the past. ${ }^{69}$

In other cases, commanders expelled wives suspected of inflaming jealousies. In 1888, the presidio's commandant wrote, "Today I sent the free civilian Rita Maria da Conceição to the Chief of Pernambuco's police to accommodate her since there are no appropriate prisons for women in the presidio. This woman is married to convict Juvencio Bispo Machado who murdered Joaquim Gaspar de Freitas, and I believe that she was the primary cause of this homicide."70 Most mainland observers recognized that jealousy was a volatile emotion that could trigger crimes of passion, yet apparently these cases never shook the overall faith placed in the jealous institution's powers.

Indeed, commanders showed clemency toward married men whose jealousy got the better of them. One convict wounded his wife with a knife, but the commander reported, "I did not bring charges against Domingos Martins Nogueira, who injured his wife in a domestic quarrel on 9 April 1877 because the injuries were slight and the life of his home as a married man is more important. Even so, I punished him ... [due to the] the necessity of [sustaining] good order in this prison." ${ }^{, 71}$ The punishment was likely a public flogging.

${ }^{68}$ Brigadeiro Francisco Joaquim Pereira Lobo ao Jose Manoel de Freitas, 22 Mar. 1884, APPJE, FN-23, no f. nos.; On the mainland, see, e.g., Martha de Abreu Esteves, Meninas Perdidas: os populares e o cotidiano do amor no Rio de Janeiro da belle époque (Rio: Paz e Terra, 1989).

${ }_{69}$ Director José Ignácio Ribeiro Roma ao Ignácio Joaquim de Souza Leão, APPJE, FN-25, 21

Nov. 1886, f. 256 and 258. For similar statements, Francisco Joaquim Pereira Lobo ao Sancho de Barros Pimentel, ibid., 22 Jan. 1885, FN-24, no f. nos.; Director José Ignácio Ribeiro Roma ao Ignácio Joaquim de Souza Leão, 21 Sept. 1886, APPJE, FN-25, f. 257.

${ }^{70}$ Joaquim Agripino Furtado Mendonça ao Joaquim José de Oliveira Andrade, 26 May 1888, APPJE, FN-27, f. 131.

${ }^{71}$ Alexandre de Barros e Albuquerque ao Presidente Adelino Antonio de Lima Freire, 17 Apr. 1878, APPJE, FN-18, f. 116. 
To support petitions for clemency, commanders often noted whether a convict had been a good worker and family man. In 1886, the commander supported Manoel José Maria's petition for pardon by writing that he had always demonstrated good conduct and through his hard work had been made the convict police company's sergeant. He added that Manoel lived with his family who he "treated with great care." 72

Many convicts sought to wed for love, companionship, labor for the house and garden, and status. Married convicts garnered better-paying convict jobs more often, and trusted convicts were more likely to be permitted to marry. Bandeira suggested, "When any prisoner intends to marry, he asks the commander's permission, and he agrees if the Church's precepts are satisfied." ${ }^{, 73}$ Evidence shows that in fact they did not allow just anyone to wed, though there were intriguing cases. Vicente de Assis Tavares' 1889 letter petitioned a new director for his release from an Aldeia jail cell where he was held in irons. His letter admitted that he had mistakenly joined in the turmoil that roiled the colony in 1885 . As proof that he had mended his ways, Vicente mentioned that he had wed months earlier, but his detention kept him from living with his "unfortunate" wife. Here Vicente manipulates ideals of husbandly duty in a bid to win release. While the commander expressed sympathy for Vicente's "disgrace," he rejected his request because of his infamy: "The notorious convict Vicente de Assis Tavares [was] the main figure behind the scenes of blood that caused so much panic and terror among the island's population." Apparently, Vicente headed a prison gang, since officials identified fifty-seven convicts as his accomplices and sent them all to Recife in 1885 . Vicente later returned to the colony, but the commander insisted that he had not changed his ways: "Vicente and Cosme José do O and [the slave convict] Sebastião ... plotted crimes and terrorized other convicts." ${ }^{.74}$ Why had a former commander let an infamous convict wed? Perhaps, like the slave owner cited earlier, he hoped nuptials would cause Vicente to "learn judgment," or maybe Vicente had impregnated his lover and she desired to wed to repair her honor. It is also possible that the commander sought to co-opt a gang leader. Whatever the case, Vicente's petition shows that marriage alone did not qualify a convict for privileges; it had to be combined with hard work, submission, and respectable family living.

The belief that greater numbers of women would curb same-sex eroticism does not appear to have been validated. In 1870, the commander reported:

\footnotetext{
72 Francisco Joaquim Pereira Lobo ao João Rodrigues Chaves, 21 Aug. 1885, APPJE, FN-24, no f. nos.

73 Bandeira, Informações, 33.

${ }^{74}$ Protesto de Francisco Joaquim Pereira Lobo ao João Rodrigues Chaves, 4 Sept. 1885, APPJE, FN-24, no f. nos.; ibid., Director Luiz Paulino de Hollanda Valença ao Manoel Alves de Araujo, 6 Nov. 1889, FN-28, f. 466; ibid., Sentenciado pobre Vicente de Assis Tavares ao Director Luiz Paulino de Hollanda Valença, 2 Nov. 1889, FN-28, f. 467-68.
} 
"The minor Raymundo Francisco Lopes ... despite his own father's efforts to correct him ... is constantly running away and hiding in the houses of convicts who use him for their libidinous ends ... [and jealousies over the boy] have led to fights. Therefore, I sent him to ... a military Arsenal, where as an apprentice he will learn a trade and may still become useful to himself and his country."75 Military apprentice schools were themselves renowned for same-sex eroticism, but the commander believed that Raymundo would have a better chance to lead a productive life there. In 1875, a commander suggested that the boys on the island be sent to the army's apprentice school to be "educated in the precepts of morality and learn to hate crime." $" 76$ In 1889, the commander sent a number of boys to military apprentice schools because their "parents did not give them the correct education and they were being raised in a vice-ridden and corrupt environment." He added that the boys made money by fishing, but "their pay was insufficient and they resorted to begging or to acts that morality repudiates." Some boys allegedly turned to prostitution to better their conditions. $^{77}$

Commanders often linked same-sex eroticism to violence and disorder. When a murder occurred among the Aldeia's "recluses" in 1873, the commander reported that it was motivated by the "nefarious vice of sodomy." larly, in 1876, when the slave convicts Ignacio and José murdered convict Henrique Pereira Cardoso, the commander stated that the motive had been robbery, but he went out of his way to relate that the assailants were lovers "continually habituated (useiros e vezeiros) in the practice of reprehensible acts and of irreconcilable conduct in this presidio against which all repressive discipline is useless." He blamed the actions of these bocaes [boçais, a derogatory term for unacculturated African-born slaves] on their ignorance and "perverse instincts." 79

It is difficult to assess the extent to which convicts believed in or cynically manipulated prescriptive ideas of marital honor and masculinity. Some allegedly cajoled, consented, tolerated, or expressed frustration about wives, daughters, and sons who turned to prostitution. Others formed alternative households with men who they lived with as consensual lovers. But commanders were not the only ones who censured indecent behavior. Convict José Antônio de

75 Sebastião Antônio do Rego Barros ao Frederico de Almeida e Albuquerque, 20 Jan. 1870, APPJE, FN-14, f. 209.

76 Brigadeiro Hygino José Coelho ao Henrique Pereira de Lucena, 3 Mar. 1875, APPJE, FN-16, f. 361 .

77 Joaquim Agripino Furtado de Mendonça ao Barão de Sousa Leão, 15 Jun. 1889, APPJE, FN-28, f. 328.

78 Antonio de Campos M. ao Henrique Pereira de Lucena, 7 July 1873, APPJE, FN-16, f. 140.

79 Major José Bonifácio dos Santos Mergulhão ao Manoel Clementino Carneiro da Cunha, 13 Sept. 1876, APPJE, FN-17, f. 209-10. 
Oliveira requested that his wife be sent to the mainland because of her immoral behavior, a petition the commander obliged. ${ }^{80}$

For inspectors, the experiment with conjugal penal living had failed. They concluded that many convicts did not behave like proper patriarchs, and they questioned the wisdom of allowing women and children to live in the colony without stricter regulation, but they also recognized some of the difficulties that families faced. They criticized the fact that families had to abandon the island after convicts finished their sentences and leave behind plots they had made productive, unlike married exiles in Australia and New Caledonia who kept their farms once they completed their sentences. They did not, however, concede that material conditions, insecurity, and gender imbalance impelled some men, women, and children to at least partially reject prescriptive ideas of honor to cope with harsh conditions. ${ }^{81}$

Most convict wives and dependents continued to live with their inmate husbands into the early Republic (1889-1930). In 1897, the colony reverted to Pernambuco's dominion, and convicts from other states were removed. While Brazil continued to experiment with penal colonies, especially during political crises, none would ever be as long-lived as Fernando de Noronha. ${ }^{82}$

\section{CONCLUSIONS}

My analysis is distinct from Foucauldian studies of prisons and sexuality that focus on transgressive behavior and Jeremy Bentham's panopticon architecture. Instead, it privileges the nuclear heterosexual family as a reputed source of male discipline and productivity in a hybrid penal regime bounded not by walls but by ocean. ${ }^{83}$ It has long been argued that the penitentiary evolved from medieval monastery practices that sought to modify individual behavior with cellular isolation. Other studies suggest that some colonial prisons developed from prisoner of war camps. I have argued here that the conjugal penal experiment on Fernando de Noronha evolved from a repertoire of Portuguese strategies to manage the labor and strategic diaspora of intractable poor men.

Could the jealous institution have applications beyond Brazil's senzalas, barracks, and Aldeia? Space allows me only to raise promising possibilities. For example, is there a connection between Brazilian coffee plantation owners' promotion of formal slave marriage and their preference for contracting Italian immigrant families in the 1880s and 1890s? Reid Andrews hints at

\footnotetext{
80 José Antonio de Oliveira ao Joaquim Agripino Furtado Mendonça, 17 Feb. 1889, APPJE, FN-28, f. 143; ibid., Joaquim Agripino Furtado Mendonça ao Innocencio Marques d'Araujo Goes, 17 Feb. 1889, APPJE, FN-28, f. 144.

${ }^{81}$ José dos Passos Queiroz ao Ignácio Joaquim de Souza Leão, 23 May 1889, APPJE, FN-28, f. 294.

82 Pessoa, Cadernos, 54.

83 Foucault, Discipline and Punish; idem., The History of Sexuality, Vol. I (New York: Vintage Press, 1990 [1976]).
} 
this when he argues that many ex-slaves avoided work conditions similar to slavery. They sought to establish their homes far from the big house and former slave barracks and to keep their female dependents from doing field or domestic work where they might be abused. For planters, this made ex-slaves less attractive employees than immigrant families. ${ }^{84}$

Further afield, French and British penal colonies made strikingly similar uses of the jealous institution to reward well-behaved convicts and populate far flung territories. In New Caledonia, male convicts could earn "tickets of leave, grants of land, and the right to marry or-if already married-the right to have their wives and families sent from France at state expense to live with them." French authorities encouraged marriage between well-behaved male and female convicts who lived segregated from one another in penal exile when they were single. Courtship was initiated by "the intended bridegroom [who] is always in possession of a cottage and a plot of land ... [and] after their marriage, the convict couple become probationary free colonists." One observer noted that this was a return to a practice common before the Revolution, when the crown exiled forçats - convicts released from the galleys on the condition that they marry a female convict and agree to transportation to Louisiana or Canada. ${ }^{85}$

While Anglophone masters resisted formal slave marriage, British authorities encouraged convict marriage in Australia. Arthur Philip made grants of land to well-disciplined male convicts who married female convicts, and officials even permitted some black convicts (former British soldiers) to marry white convict wives. In Tasmania, where single female convicts were house in separate barracks, married convicts lived in their own private households. Since male convicts greatly outnumbered females in both colonies (by five to one in Australia), authorities could be quite choosy about which men they granted this privilege to. It seems that the penal colonization project overcame imperial cultural and religious distinctions as authorities wanted to people their possessions. This contrasted with Fernando de Noronha, where families were returned to the mainland when convicts completed their sentences or died. $^{86}$

Beyond comparative penal colonization, an understanding of the jealous institution might elucidate live-in labor practices elsewhere. For example,

\footnotetext{
${ }^{84}$ Andrews, "Black and White Workers: São Paulo, Brazil, 1888-1928," Hispanic American Historical Review 68, 3 (1988): 514-18; Verena Stolke, "Trabalho e moralidade familiar," 171215, in Olívia Maria Gomes da Cunha e Flávio dos Santos Gomes, eds., Quase cidadão: Histórias e antroplologias da pós-emancipação no Brasil (Rio: Editoria Fundação Getulio Vargas, 2007).

85 "French Convict Marriages," Chamber's Journal of Popular Literature, Edinburgh, 4 Aug. 1883: 486-87; Peter Redfield, Space in the Tropics: From Convicts to Rockets in French Guiana (Berkeley: University of California Press, 2000), 197.

${ }_{86}$ John West, History of Tasmania, 2 vols. (Launceston: Henry Dowling, 1852), II, 181-82; Cassandra Pybus, Black Founders: The Unknown Story of Australia's First Black Settlers (Sydney: University of New South Wales Press, 2006), 91-92.
} 
Raffeala Sarti's survey of domestic servants and marriage in Europe from the sixteenth through the nineteenth centuries shows that employers usually allowed trusted male live-in servants to marry after years of loyal service, and when they did most established a private domicile. Conversely, when live-in female domestics married, most chose to leave their employment as domestics or their employers dismissed them. This case illustrates the gender distinction between jealous and greedy institutions. ${ }^{87}$ The jealous institution might also illuminate life and labor in company towns. Recent research on Chilean mining towns, for instance, has highlighted how employers privileged married miners in hiring and provided them separate family homes, while bachelor workers lived in barracks. Their employers believed married miners would be less prone to labor radicalism and that having more married workers would stem turnover. ${ }^{88}$

British historian Douglas Hay recently remarked on the salience of medicalized discourse in Ibero-American rhetoric on criminality relative to that in Britain and Anglo-America. Nineteenth-century English law stressed marketwise individual accountability: "The courts would not save you from your mistakes; the population had to be educated into risk-taking, entrepreneurial individualism." ${ }^{89}$ My case study reveals that one might add family, gender, class, and sexuality to the medicalized discourses that Hay singles out. Conjugal penal living contrasts with individualized North Atlantic penal practices, and highlights distinct cultural views of male sexuality. Brazilian officials accommodated some poor patriarchs, even when convicted of homicide, because they feared that by jailing a husband and father the state could victimize innocent wives and dependents.

This present case study has highlighted parallels in how authorities regulated the jealous institution among the intractable poor men in total institutions. As Robert Slenes and others have argued, slave marriage is a story of subordinates pushing for rights within the limited horizons of bondage, where the rights to wed, establish a private household, and work a provision ground likened their status to that of free share croppers, or what Sidney Mintz termed a "slave peasantry." 90 Some masters felt that marriage was compatible with bondage, but as

${ }^{87}$ Raffeala Sarti, “'All Masters Discourage the Marrying of Their Male Servants and Admit Not by Any Means the Marriage of the Female': Domestic Service and Celibacy in Western Europe from the Sixteenth to the Nineteenth Century," European Historical Quarterly 38, 3 (2008): 417-49. For similar tensions over domestics and living arrangements in Brazil, see Lauderdale Graham, House and Street.

${ }^{88}$ See, e.g., Angela Vergara, Copper Workers, International Business, and Domestic Politics in Cold War Chile (University Park: Pennsylvania State University Press, 2008), 37-38; Klubock, Contested Communities.

89 Douglas Hay, "Afterward: Law and Society in Comparative Perspective," in Ricardo D. Salvatore, Carlos Aguirre, and Gilbert Joseph, eds., Crime and Punishment in Latin America: Law and Society since Late Colonial Times (Durham: Duke University Press, 2001), 415-30.

90 Sidney Mintz, Carribean Transformations (Chicago: Aldine Pub. Co., 1974). 
Sandra Lauderdale Graham shows, slaves could "say no" to match-making masters, and Slenes cautions that family ties provided slaves with new capacities and reasons to resist. Lauderdale Graham critiques Slenes for overstating the degree to which masters allowed their slaves to wed as part of, in her words, a "deliberately formed strategy of persistent manipulation." She feels that "more mundane explanations suffice," and states that Brazilians "generally found family a useful way of ordering society, their own slaves included." agree, but only a minority achieved nuptials. Lauderdale Graham adds that there is no "detailed, persuasive evidence for their [masters'] intentionality" in permitting slave marriage. A dearth of sources frustrates attempts to establish masters' motives for allowing slave marriage.

If one looks beyond the slave regime, however, patterns appear in how superiors regulated the jealous institution within total institutions that incorporated the intractable poor. The parallels at the very least suggest a more conscious policy of using conjugality to rank, reward, and discriminate among intractable poor laborers. This probably does not rise to Lauderdale Graham's idea of a "deliberately formed strategy of persistent manipulation," but she may be setting the bar too high given that, as the present case shows, the decisions made by subordinates and those who permitted them to marry or to live with a lover were not singular but multifarious.

Fernando de Noronha's conjugal penal living left only faint twentiethcentury echoes. In Taubaté and Neves, in the states of São Paulo and Minas Gerais respectively, officials built agricultural penal colonies that let married convicts live with their wives and dependents. These institutions were poorly funded, however, and too small to harbor but a portion of the married inmates. ${ }^{92}$ An even more distant resonance is heard in justifications for conjugal prison visits. Clearly, conjugal visits are distinct from the cases of conjugal living I have examined here, but one way in which some warders rationalized them is strikingly similar. When the director of São Paulo's 35th Police District was asked in 1997 what options he had for promoting order among male prisoners, he replied without hesitation: "The [conjugal] visits. Their greatest concern is that someone will prohibit the visits of their lovers [namoradas].",93

Based on these comparisons, Brazilian institutions that harbored the intractable poor often used marriage and conjugal living as a means to rank, reward, and discriminate among them. Color and civil condition influenced the chances that intractable poor men had to achieve marriage and other privileges, and they could form mutually reinforcing hierarchies. But there were intriguing

91 Sandra Lauderdale Graham, Caetana Says No: Women's Stories from a Brazilian Slave Society (New York: Cambridge University Press, 2002), 32; Slenes, Na senzala.

92 Astor Guimarães Dias, A questão sexual nas prisões (São Paulo: Saraiva, 1955), 70.

93 “'O Contato dos presos com o mundo exterior': O Brasil atrás das grades," Human Rights Watch Website, 1997.http: //199.173.149.140/portuguese/reports/presos/agrad.htm (accessed 14 Aug. 2007). 
exceptions. For instance, marriage and bondage legally protected men from military impressment, but "whiteness" did not. Poor white men were underrepresented among enlisted men and convicts, but authorities did not police a firm line of segregation based on color or civil condition at these lower social margins in basic institutions. Outside of slavery, Brazilian institutions that incorporated the intractable poor more often lumped them all together regardless of their color or condition.

In analyses of the stratification of the Brazilian poor, marital status and kinship have received less attention than race and legal condition, but powerful actors often privileged them. B. J. Barickman hints at this in his analysis of the 1835 census of Iguape, Bahia: "Thus acknowledgement of kinship_far more so than 'quality' or color, as an indication of known African ancestry or birthserves within the census to distinguish free residents from slaves." 94 The stereotype of slaves living wantonly outside of family reinforced discrimination against them, but marriage was also a means of discriminating among them. The exercise of kinship ties could ameliorate conditions in the Aldeia, senzala, and barracks, but that does not mean that everyone sought them or could achieve them. Indeed, the concern with this distinction appears strongest in the minds of authorities responsible for managing intractable poor laborers. In the senzala, the barracks, and the Aldeia, good behavior, hard work, and marriage marked respectability, but these privileges could be curtailed or abrogated if household heads or dependents became disorderly or indolent. Given the evidence I have presented here, it seems unlikely that these strategies really gave masters, officers, or warders greater leverage with subordinates, but that they practiced similar strategies in such varied settings reveals their enduring conviction that they were effective.

94 Barickman, "Reading the 1835 Parish," 308. 